\title{
Dr W J A Payne: an appreciation
}

\author{
R Trevor Wilson
}

Accepted: 6 October 2008 / Published online: 29 November 2008

(C) Springer Science + Business Media B.V. 2008

I first became aware of W J A Payne in the early 1960s, recently arrived in Tanganyika [now Tanzania] to work on what remained of the infamous (and since almost completely misunderstood) Groundnut Scheme. The groundnuts had failed and most farms were being converted to cattle ranches. I was given the job effecting this conversion at the Nachingwea farms in the Southern Province. To assist me in this task the company provided a First Edition copy of "Williamson and Payne". "An Introduction to Animal Husbandry in the Tropics" was first published, 435 pages in length, in 1959 and was very quickly reprinted in 1960, then in 1963 and again in 1964. Already a seminal work, a Second Edition of 447 pages was published in 1965. I very quickly got my employers in Dar es Salaam to invest 65 shillings (then $£ 3$ and 5 shillings or now $£ 3.50 \mathrm{p}$ ) in this new work. To my subsequent and no doubt eternal regret I binned the First Edition. I have been unable to ascertain how many reprints of the Second Edition there were but a Third Edition published in 1978 was reprinted at least three times up to 1987. The book was now 755 pages in length and the price in the UK was the enormous sum of $£ 38$. A Fourth Edition of 881 pages with Bill Payne as the sole author was

R. T. Wilson $(\triangle)$

Bartridge House,

Umberleigh,

Devon EX37 9AS, UK

e-mail: trevorbart@aol.com published 1990 and again the number of reprints is unknown. These four editions were published by Longman but during the 1990s they divested their agricultural interests to Blackwell-Wiley. The latter almost immediately commissioned a Fifth Edition but in many respects a new book - which was published in 1999 with Payne and Wilson as authors. The Fifth Edition was only 815 pages long but was in a larger format and so contained much more information and has been described as "still the most authoritative and comprehensive book on the development and production of domestic livestock in the tropics". A Spanish translation with the title "La ganadería en regiones tropicales" was published by Ed. Blume SA in 1975. In addition to the commercial editions the Educational Low-Priced Books Scheme published the First Edition in 1965, the Second Edition and three reprints between 1968 and 1975, the Third Edition and five reprints between 1978 and 1989 and the Fourth Edition at least two reprints between 1990 and 1994. More than one hundred thousand copies of the "Introduction" have been sold throughout the world. Citations of these works number many hundreds of thousands. Regrettably, at a cover price of $£ 117$, the Fifth substantive edition has proved beyond the reach of many private individuals and indeed many institutional buyers. This has not prevented scientists from continuing to cite earlier editions in their own publications. Attempts by authors and publishers of many other countries and nationalities have singularly failed to dent the pre- 
eminent position of the iconic "Introduction" in the scientific and technical literature on tropical livestock.

William John Arthur Payne was born on 12 January 1918 in the village of Broadway in Worcestershire in the English West Midlands. He was ever after inordinately proud of this accident of birth and on every possible occasion told any one who cared to listen that Broadway was the only Cotswold village in Worcestershire. He attended the local primary school and then did his secondary schooling at Evesham Grammar School. Thence he won a Scholarship to Cambridge and went up in 1938. He graduated M.A. in Agriculture in 1942 and also obtained the prestigious Diploma in Agriculture. He then went on to a post at the West of Scotland Agricultural College in Ayr. The work he carried out there resulted in the award of a Ph.D., with a specialization in Animal Nutrition, from the University of Glasgow. Whilst at Cambridge, Bill met and married Selma (a refugee from Nazi persecution). In 2008 the 67 years of marriage of Bill and Selma was celebrated with their three sons and one daughter, a whole tribe of grandsons and granddaughters and several greatgrandchildren.

Following the award of his Ph.D. Bill joined the Colonial Service. In early April 1949 the prestigious journal "Nature" listed recent appointments to the Colonial Service. Amongst those mentioned was W. J. A. Payne who was assigned as an Animal Husbandry Officer to Fiji. By coincidence, the same announcement indicated that G. Williamson had been appointed to the post of Temporary Veterinary Education Officer in Nigeria. Bill very quickly settled into his work in the South Pacific and very soon was publishing papers on various aspects of tropical animal production. In a little over two years from his initial Colonial Office posting Bill's name again appeared in Nature, this time as the principle author of a paper on the grazing habits - and thus incidentally the adaptation - of tropical cattle (Payne et al. 1951). (I well remember a photograph in the early editions of the "Introduction" which showed zebu cattle grazing in the heat of the day whilst a group of Bos taurus huddled under a tree for shade.) This interest in livestock-feed relations was continued in a following paper relative to pasture research in Fiji (Payne et al. 1955). His early interests in the South Pacific also extended to an important animal in that area, the pig (Payne et al. 1954). Although his later interests centred mainly on cattle Bill continued to maintain an affection for swine and insisted on rewriting, himself, the chapter on this species in the Fifth Edition of the "Introduction". At this initial stage of his career he had already recognized the need to move away from conventional to unconventional feeds to reduce both the competition between livestock and people and the costs of production (Payne 1956).

During the mid 1950s the Payne centre of interest moved from the South Pacific to South-East Asia. In the Philippines and under the auspices of the United Nations Development Programme (UNDP) Bill worked at the College of Agriculture and concurrently developed training materials and courses for UNDP's Dairy Training and Research Institute (Tsai et al. 1967). It was during this period that Bill's interests turned to the development and use of appropriate livestock resources for South-East Asia (Payne 1965a, 1966). He also recognized and publicized the need for "horses for courses" (the use of adapted resources for particular situations) (Payne 1967) and the need for identifying, conserving and using local and nonconventional livestock genetic resources (Payne and Rollinson 1973).

In the early 1960s Bill was appointed Deputy Director of the East African Agriculture and Forestry Research Organization (EAAFRO) based at Muguga in Kenya. From being steeped in the humid tropics of the far distant eastern hemisphere he turned his talents not only to the problems of livestock in the drier areas of Africa (Payne 1965b) but also to their contribution to human livelihoods, food security and welfare (Payne 1962). This probably led to another major contribution to the livestock sciences. The question was: where did domestic cattle come from? An indepth study was initiated on their origins, first of all for those in Africa (Payne 1965c) and then, in another major opus, on the whole gamut of tropical cattle (Payne and Hodges 1997). Early in his tenure in East Africa Bill returned to one of his earlier interests, that of adaptive behaviour to local conditions (Payne and Macfarlane 1963). It was not only behavioural adaptations but also the physiological ones of domestic livestock that captured Bill's attention at this time (Hutchison and Payne 1963). Although he was a dedicated scientist Bill always tried to ensure that his research had a practical and not just a theoretical outcome (Payne 1968). One major philanthropic body (Rockefeller 1962) described him during his time at 
Muguga as "a specialist on the nutrition and management of cattle... [who planned]...to expand his research to compare the abilities of different species of cattle and wild animals to survive and to produce meat and milk in drought-stricken areas, and in regions where the forages are low in protein value". It went on to provide a grant of US\$ 20000 - a much larger sum than almost all the grants awarded to individuals in that year - for a mobile laboratory and associated equipment. The Rockefeller citation gives a hint of another research interest of Bill's, that of the complementarity between domestic stock and wild game in the use of natural resources (Ledger et al. 1965). The genesis of the "Introduction" also occurred in Kenya when Graham Williamson made a visit there to discuss the possibilities of and need for such a text book.

Retiring from full time employment in the late 1960s to devote more time to writing, Bill produced another monograph on tropical livestock (Payne 1970). "Cattle production in the tropics, Volume 1" (I later asked Bill whatever happened to Volume 2 but he was unable or unwilling to give an explanation) did not have as big an effect as the "Introduction" but was nonetheless a major work. Other interests to which he devoted attention once the burden of daily work had been removed were the integration of livestock with other natural resources (Payne 1976a, 1985) and the description and classification of production systems (Payne 1976b). "Retirement" was not a neutral gear for Bill and he continued to share his knowledge for several years through a Visiting Professorship at the University of Florida in Gainesville for several years during the 1970s.

Having become aware of WJA Payne in the early 1960s (as explained earlier) I met him in the flesh in May 1973. We (I, my wife and 4-year old son) were working on the design of a project that should have resulted in the development of the natural resources of Southern Darfur in Sudan. Bill was employed short term to oversee the livestock work and came to stay with us on a supervision visit. We had a hectic - not to say frenetic - two weeks of work and play (climbing Jebel Marra) during which time he persuaded me to write up the results of the Darfur studies for formal publication. Tropical Animal Health and Production was the target journal (Bill said the its first editor W C Beaton was a friend of his although I am sure that did not influence the acceptance of the paper). My first publication, written jointly with S E Clarke, was published in 1975. It was followed by a second joint paper and then a further six papers in the Southern Darfur series over the next few years.

The life paths of WJA Payne and RT Wilson crossed many times after that first meeting. Bill always encouraged me and was ever willing to share his experiences and knowledge. He did this, of course, for many thousands of other people and not least for Selma with whom he produced a cookery book (Payne and Payne 1979). In assembling this Special Issue to commemorate Dr Payne's work and his contribution to the knowledge and development of tropical animal production the basic concept was to produce papers relative to the geographical locations of his work and his areas of scientific interest. We have not been entirely successful in this objective but, such is Bill's contribution and influence, that almost any paper written on tropical livestock would pay homage to him in some measure.

\section{References}

Hutchison HG and Payne WJA. 1963. Water metabolism of cattle in East Africa - 1, the problem and the experimental procedure. Journal of Agricultural Science (Cambridge) 61: 255-268.

Ledger HP, Payne WJA, Talbot LM, Talbot MH and Verdcourt LD. 1965. The meat production potential of wild animals in Africa - a review of biological knowledge (Technical Communication No 16). Commonwealth Agricultural Bureau: Farnham Royal, England.

Payne WJA. 1956. Ipomoea reptans Poir., a useful tropical fodder plant. Tropical Agriculture (Trinidad) 33: 302-305.

Payne WJA. 1962. Relation of animal husbandry to human nutritional needs in East Africa. East African Agricultural and Forestry Journal 29: 17-25.

Payne WJA. 1965a. Development of animal husbandry resources in South East Asia. Paper presented at the Conference on Conservation of Nature and Natural Resources in Tropical South East Asia - Bangkok, Thailand, 29 November-4 December 1965. 1-11.

Payne WJA. 1965b. Specific problems of semi-arid environments. Qualitas Plantarum Et Materiae Vegetabiles 12: 269-294.

Payne WJA. 1965c. The origin of domestic cattle in Africa. Empire Journal of Experimental Agriculture 32: 97-113.

Payne WJA. 1966. The role of the cattle industry in the Philippines. Paper presented at Third Scientific Conference on Animal Science - Manila, Philippines, 24-25 June 1966. 1-28.

Payne WJA. 1967. Environmental limits to productivity and effect of this on choice of breed. In: Proceedings of the First Cattle Production Business Executive Course, 
Laguna, Philippines, 12-19 May 1967. UNDP/SF Project Phi/4, Dairy Training and Research Institute: Laguna, Philippines. $37-41$.

Payne WJA. 1968. White collar research - A luxury. Ceres/FAO Review 1(3): 46-49.

Payne WJA. 1970. Cattle production in the tropics (Volume 1). Longman Group Limited: London, UK.

Payne WJA. 1976a. Possibilities for the integration of tree crops and livestock production in the wet tropics. Journal of the Science of Food and Agriculture 27: 888.

Payne WJA. 1976b. Systems of beef production in developing countries. In: Smith AJ (ed) Beef cattle production in developing countries (Proceedings of the Conference held in Edinburgh from the 1st to 6th September 1974). Centre for Tropical Veterinary Medicine, University of Edinburgh: Edinburgh, UK. 118-131.

Payne WJA. 1985. A review of the possibilities for integrating cattle and tree crop production systems in the tropics. Forest Ecology and Management 12: 1-36.

Payne WJA. 1991. Domestication: a step forward in civilization. In: Hickman CG (ed) Cattle genetic resources (World Animal Science Volume B7). Elsevier Health Sciences: Amsterdam, The Netherlands. 51-72.

Payne WJA and Hodges J. 1997. Tropical cattle: origins, breeds and breeding policies. Blackwell Science: Oxford, UK.
Payne WJA and MacFarlane JS. 1963. A brief study of cattle browsing behaviour in a semi-arid area of Tanganyika. East African Agriculture and Forestry Journal 29: 131-133.

Payne S and Payne WJA. 1979. Cooking with exotic fruit. Batsford: London, UK.

Payne WJA and Rollinson DHL. 1973. Bali cattle. World Animal Review 7: 13-21.

Payne WJA and Smith AJ. 1975. Factors limiting the production of animal products in the tropics, with particular reference to animal feeds. Proceedings of the Conference on Animal Feeds of Tropical and Subtropical Origin. Tropical Products Institute: London, UK. 23-32.

Payne WJA, Laing WI and Raivoka EN. 1951. Grazing behaviour of dairy cattle in the tropics. Nature 167: 610-611.

Payne WJA, Naidu RK and Sills VE. 1954. The relative value and economy of porkers in Fiji. Fiji Agricultural Journal 25: 65-70.

Payne WJA, Laing WI, Miles NS and Mason RR. 1955. Fodder and pasture investigational work at Sigatoka, 1949-53. Fiji Agricultural Journal 26: 38-60.

Rockefeller. 1962. Annual Report for 1962. The Rockefeller Foundation: New York, USA.

Tsai YC, Castillo LS, Hardison WA and Payne WJA. 1967. Effect of dietary fiber level on lactating dairy cows in the humid tropics. Journal of Dairy Science 50: 1126-1129. 